\title{
Determination of Residual Antibiotics in Cryopreserved Heart Valve Allografts
}

\author{
Ramadan Jashari $^{\mathrm{a}}$ Françoise Faucon $^{\mathrm{b}}$ Beatrice Van Hoeck ${ }^{\mathrm{a}}$ Seppe De Gelas ${ }^{\mathrm{b}}$ Yedong Fan ${ }^{\mathrm{a}}$ \\ Stephane Vandenbulcke ${ }^{\mathrm{b}}$
}

a European Homograft Bank (EHB), International Association, Military Hospital Queen Astrid,

${ }^{b}$ Laboratoire de Contrôle et d'Analyse s.a. (LCA), Brussels, Belgium

\section{Keywords}

Allograft - Cryopreservation - Heart valves . Residual antibiotics

\section{Summary}

Introduction: Cardiovascular allografts are systematically incubated in antibiotics for their decontamination, and the antibiotics are removed before allograft implantation. We studied the occurrence of antibiotic residues in allograft valves. Methods: 12 experimental allografts were analyzed in this study. The concentration of the residual antibiotics was determined by high-performance liquid chromatography and the results were expressed as microgram per gram of allograft tissue. Results: The initial analysis showed that only vancomycin $\mathrm{HCl}$ and lincomycin $\mathrm{HCl}$ were retained in the allograft, whereas no traces of polymyxin B sulfate were detected in the tissue samples. Furthermore, the values found for the antibiotic residues in the extracted solution from the allografts were similar to the initial results: Vancomycin and lincomycin were detected in very low concentrations and no polymyxin $B$ residues were observed. According to the World Health Organization (WHO), the maximum daily doses for vancomycin, lincomycin and polymyxin B are 2.0, 1.8 and $0.4 \mathrm{~g}$, respectively. The thresholds for reporting degradation products are $0.05 \%$ for vancomycin and lincomycin and $0.1 \%$ for polymyxin $\mathrm{B}$. The residual values for the two detected antibiotics were largely below $0.05 \%$. Conclusions: Antibiotic residues in the allograft valves do not present any risk for their recipients. Increased allograft resistance to infections is probably due to the retention of antibiotics in the tissue.

\section{Schlüsselwörter}

Allotransplantat · Kryokonservierung $\cdot$ Herzklappen . Restantibiotika

\section{Zusammenfassung}

Einleitung: Kardiovaskulare Allotransplantate werden zur Dekontamination systematisch zusammen mit Antibiotika inkubiert; die Antibiotika werden vor der AllotransplantatImplantation wieder entfernt. In der vorliegenden Studie wurden Herzklappentransplantate auf das Vorhandensein von Antibiotikaresten untersucht. Methoden: 12 experimentelle Allotransplantate wurden in dieser Studie untersucht. Die Konzentration von Restantibiotika wurde mittels Hochdurchsatz-Flüssigkeitschromatographie bestimmt und die Ergebnisse als Mikrogramm pro Gramm AllotransplantatGewebe ausgegeben. Ergebnisse: Die initiale Analyse ergab, dass lediglich Vancomycin $\mathrm{HCl}$ and Lincomycin $\mathrm{HCl}$ in den Allotransplantaten zurückgeblieben waren, während von Polymyxin-B-Sulfat keine Spuren in den Gewebeproben nachgewiesen werden konnten. Darüber hinaus waren die Konzentrationen der Antibiotikareste in der von den Allotransplantaten extrahierten Lösung ähnlich wie die initialen Ergebnisse: Vancomycin und Lincomycin wurden in sehr geringen Dosen gefunden, Polymyxin B ließ sich nicht mehr nachweisen. Gemäß der World Health Organization (WHO) sind die maximalen täglichen Dosen für Vancomycin, Lincomycin bzw. Polymyxin B 2,0, 1,8 bzw. 0,4 g. Die Schwellenwerte für den Nachweis von Abbauprodukten sind 0,05\% für Vancomycin und Lincomycin sowie $0,1 \%$ für Polymyxin B. Die nachgewiesenen zwei Antibiotika-Restkonzentrationen in den Herzklappen-Allotransplantaten liegen weiter unter dem Schwellenwert von 0,05\%. Schlussfolgerung: Antibiotikareste in Herzklappen-Allotransplantaten stellen kein Risiko für die Transplantatempfänger dar. Eine erhöhte Allotransplantat-Resistenz gegen Infektionen wird möglicherweise durch die Retention von Antibiotika im Gewebe bewirkt.

\section{KARGER}

Fax +497614520714

Information@Karger.de

www.karger.com

\section{(C) 2011 S. Karger GmbH, Freiburg}

Accessible online at:

www.karger.com/tmh

Ramadan Jashari, MD, FETCS

European Homograft Bank (EHB), International Association

c/o Military Hospital Queen Astrid

Rue Bruynstraat 200, 1120 Brussels, Belgium

Tel. +32-2 2644066, Fax -477915631

ehb.jashari@skynet.be 


\section{Introduction}

The procured human heart valves and/or arteries for allograft preparation are contaminated in approximately $25-70 \%$ of cases, depending on the donor type and the retrieval conditions [1]. Exposure to low concentrations of different antibiotics during the $20-48 \mathrm{~h}$ before cryopreservation reduces the contamination rate to about $5-10 \%$ [2, 3]. Different Tissue Establishments worldwide, responsible for cardiovascular allograft decontamination, have adopted different cocktails of antibiotics, under different temperature conditions and for varying duration [4-6]. Since the cell viability preservation of the heart valves signifies the valve quality preservation [7], many antibiotics such as antimycotic drugs [8] were removed from some decontamination protocols. Some long-term studies on implanted allografts have shown that allograft viability is a prerequisite for graft survival [7-9]. Although the antibiotic cocktail is referred to as low dose, the concentrations are far in excess to the doses used clinically for the treatment of systemic infections and well above the concentrations required to inhibit most microorganisms [10].

The European Homograft Bank (EHB) has been processing the heart valve and vascular allografts since 1989. The allografts are systematically incubated in the antibiotic cocktail. Before allograft implantation into the patient's body, all the processing components, such as the antibiotics, dimethyl sulfoxide (DMSO) and the medium 199, are removed by rinsing the tissue in isotonic solution (saline). Although the concentration of antibiotics is strongly reduced, for validation purposes the residues of these antibiotics in the allograft should be investigated. This study was carried out to determine the residual concentrations of the antibiotics used in the EHB cocktail for allograft decontamination. The technique used for this purpose was high-performance liquid chromatography (HPLC) carried out according to the European Pharmacopoeia 6th edition and the Pharmeuropa vol. 20, no. 1 (2008).

\section{Material and Methods}

The heart valves were obtained from: (a) multi-organ donors (MOD), (b) recipients of heart transplantation (RHT) or (c) cadaveric, nonheart-beating donors (NHBD), according to the EHB donor selection criteria for cardiovascular allograft preparation [10]. The heart valves that were morphologically not suitable for clinical use were discarded: 6 aortic valves (AVs) and 6 pulmonary valves (PVs) were used as the experimental allografts for this study. The cocktail of antibiotics was composed of: vancomycin $\mathrm{HCl}$ (vancocin, GlaxoSmithKline, Wavre, Belgium), lincomycin $\mathrm{HCl}$ (lincocin, Pfizer, Brussels, Belgium) and polymyxin B sulfate (polymyxin B sulfas, Fagron, Colombes, France). The antibiotics were added to $250 \mathrm{ml}$ of medium 199 with Hank's salts, L-glutamine and $25 \mathrm{mmol} / \mathrm{l} \mathrm{Hepes} \mathrm{(MEM} \mathrm{199;} \mathrm{Invitrogen)} \mathrm{to} \mathrm{a} \mathrm{final} \mathrm{con-}$ centration of $50 \mu \mathrm{g} / \mathrm{ml}$ for vancomycin $\mathrm{HCl}, 120 \mu \mathrm{g} / \mathrm{ml}$ for lincomycin $\mathrm{HCl}$, and $124 \mu \mathrm{g} / \mathrm{ml}$ for polymyxin B sulfate. The allografts were immerged in the cocktail of antibiotics at $+4{ }^{\circ} \mathrm{C}$ for $48 \mathrm{~h}$ in sterile, hermeti- cally closed Maco Biotech freezing-storage pots (MacoPharma, Mouvaux, France). The study was carried out in 2 phases: The initial testing was conducted for each antibiotic separately, whereas during the second phase the EHB antibiotics cocktail containing all 3 antibiotics was tested.

For the preliminary testing, $3 \mathrm{AVs}$ and $3 \mathrm{PVs}$ were separated longitudinally into 3 equivalent fragments, each fragment containing the corresponding valve leaflet. 1 fragment was incubated in MEM 199 without antibiotic ('negative' control sample). 2 other fragments were incubated in MEM 199 containing the antibiotic to be tested. 1 of these 2 fragments was used as 'positive control' (coming directly from the antibiotic cocktail without rinsing), the other fragment (testing sample) was rinsed in the $+4{ }^{\circ} \mathrm{C}$ cold saline solution, gradually added in intervals of 1 min $(10-20$ $-70 \mathrm{ml}$ ) following the EHB thawing and dilution protocol. Subsequently, the tissue was transferred and left for $1 \mathrm{~min}$ in a new receptacle containing $50 \mathrm{ml}$ of cold saline solution $\left(+4{ }^{\circ} \mathrm{C}\right)$ [11].

In the second phase of the study, $3 \mathrm{AVs}$ and $3 \mathrm{PVs}$ were decontaminated, cryopreserved and stored in the vapor phase of liquid nitrogen according to the EHB protocol, as described previously [11]. The valves were thawed and the cryoprotection solution (DMSO) was diluted from 10 to $0 \%$ following the EHB protocol [11]. One third of each valve was removed and the remaining two thirds were rinsed as mentioned above in $20-40-140 \mathrm{ml}$ of the cold saline solution $\left(+4^{\circ} \mathrm{C}\right)$.

All tested allograft tissues were destructed and reduced to small pieces. Approximately $1 \mathrm{~g}$ of each sample was embedded in $10 \mathrm{ml} \mathrm{HPLC}$ water for ultrasound extraction during $30 \mathrm{~min}$ at room temperature. After sedimentation, 3-5 $\mathrm{ml}$ of this solution was filtered through a 0.45 $\mu \mathrm{m}$ filter membrane to remove particles greater than $0.45 \mu \mathrm{m}$, and analyzed. HPLC for each antibiotic was performed on a Pursuit reversedphase $\mathrm{C} 18$ column (length: $150 \mathrm{~mm}$, diameter: $4.6 \mathrm{~mm}$, particles: $5 \mu \mathrm{m}$, at room temperature for vancomycin $\mathrm{HCl}$ and lincomycin $\mathrm{HCl}$ or at $30{ }^{\circ} \mathrm{C}$ for polymyxin B sulfate). Quantification of the residual antibiotics was accomplished using triethylamine/water/phosphoric acid/tetrahydrofuran/acetonitrile as the mobile phase at the detection wavelength of 280 $\mathrm{nm}$ for vancomycin $\mathrm{HCl}$, phosphoric acid/water/acetonitrile/methanol at the detection wavelength of $210 \mathrm{~nm}$ for lincomycin $\mathrm{HCl}$, and anhydrous sodium sulfate/water/acetonitrile at the detection wavelength of $215 \mathrm{~nm}$ for polymyxin B sulfate. The equipment used for this study was an HPLC Hitachi Lachrom Elite system and the software was EZ-Chrom - Elite. For analysis, 5 samples were taken from each solution. The results are expressed as microgram of antibiotic per milliliter of examined extraction solution.

The limit of detection (LOD) and the limit of quantification (LOQ) were calculated from the standard deviation of the response and the slope of the curve of each antibiotic according to the International Conference on Harmonization (ICH) guideline Q2B (Validation of Analytical Procedures, European Medicines Agency (EMEA)) [12, 13], where the LOQ = $3 \times$ LOD. The quantity of each residual antibiotic in the extraction solution was determined on the respective calibration curve.

\section{Results}

Of the tested antibiotics, 2 were retained by the allograft tissues at, on average, 3.14\% for vancomycin $\mathrm{HCl}$ (AVs 3.56\%, $\mathrm{PVs} 2.73 \%$ ) and $0.61 \%$ for lincomycin $\mathrm{HCl}$ (AVs $0.56 \%$, PVs $0.65 \%)$. There were no traces of residual polymyxin B sulfate in the tissue samples (table 1). There was no interference between the antibiotics and the allograft valve tissues. 2 of the antibiotics were adsorbed by the allograft tissues and leached out during the extraction procedure.

Since 2 of the 3 antibiotics were detected in the allograft tissue during the preliminary testing, additional tests were 
Table 1. Initial testing for residual antibiotics after incubation in the EHB cocktail

\begin{tabular}{llll}
\hline Antibiotic & Tissue & $\begin{array}{l}\text { Antibiotics residues in } \\
\text { the tissue detected by } \\
\text { HPLC, } \mu \mathrm{g} / \mathrm{g}\end{array}$ & $\begin{array}{l}\text { Residual antibiotics based } \\
\text { on initial concentration in } \\
\text { MEM 199, \% }\end{array}$ \\
\hline Vancomycin $\mathrm{HCl}$ & $\mathrm{AV}$ & 17.27 & 3.56 \\
& $\mathrm{PV}$ & 30.87 & 2.73 \\
Lincomycin $\mathrm{HCl}$ & $\mathrm{AV}$ & 13.4 & 0.56 \\
\multirow{2}{*}{ Polymyxin B } & $\mathrm{PV}$ & 34.76 & 0.65 \\
& $\mathrm{AV}$ & 0.00 & 0.00 \\
& PV & 0.00 & 0.00 \\
\hline \multirow{2}{*}{ AV = Aortic valve; PV } & pulmonary valve. \\
\hline
\end{tabular}

\begin{tabular}{llll}
\hline Antibiotic & Tissue & $\begin{array}{l}\text { Antibiotics residues } \\
\text { detected by HPLC in } \\
\text { tested tissue, } \mu \mathrm{g} / \mathrm{g}\end{array}$ & $\begin{array}{l}\text { Residual antibiotics based } \\
\text { on initial concentration in } \\
\text { MEM 199, \% }\end{array}$ \\
\hline Vancomycin HCl & AV (nr) & 18.14 & 0.88 \\
& AV (r) & 10.74 & 0.65 \\
& PV (nr) & 16.67 & 1.01 \\
Lincomycin HCl & PV (r) & 11.92 & 0.72 \\
& AV (nr) & 6.72 & 0.14 \\
& AV (r) & 8.44 & 0.21 \\
Polymyxin B & PV (nr) & 7.58 & 0.19 \\
& PV (r) & 8.68 & 0.22 \\
& AV (nr) & 0.00 & 0.00 \\
& AV (r) & 0.00 & 0.00 \\
PV (nr) & 0.00 & 0.00 \\
AV = Aortic valve; PV $=$ & pulmonary valve; nr = not rinsed; r r rinsed. \\
\hline
\end{tabular}

Table 2. Residues of antibiotics in the heart valve allograft tissue (second phase) carried out on allografts that were treated following the EHB protocol for allograft preparation, storage and thawing. The residues of antibiotics in the EHB heart valve allografts prepared by standard method amounted to, on average, $0.81 \%$ of vancomycin $\mathrm{HCl}$ (AVs $0.76 \%$, PVs $0.86 \%$ ) and $0.18 \%$ of lincomycin $\mathrm{HCl}$ (AVs $0.17 \%$, PVs $0.20 \%$ ). Again, no residues of polymyxin B sulfate were detected. The results are expressed as percentage of the initial dose of each antibiotic for $1 \mathrm{~g}$ of decontaminated tissue (table 2).

The concentrations of the antibiotics in the extraction solution in the calibration curve were close to the quantity of the
Table 3. Residual antibiotics values: Percentage of antibiotics in the non-rinsed and rinsed allografts compared to the threshold of the respective antibiotic

\begin{tabular}{lll}
\hline Allograft & $\begin{array}{l}\text { Vancomycin HCl, } \\
\%\end{array}$ & $\begin{array}{l}\text { Lincomycin } \mathrm{HCl}, \\
\%\end{array}$ \\
\hline $\begin{array}{l}\text { Aortic } \\
\quad \text { Non-rinsed }\end{array}$ & 0.019 & \\
$\quad$ Rinsed & 0.016 & 0.018 \\
Pulmonary & & 0.009 \\
$\quad$ Non-rinsed & 0.031 & \\
$\quad$ Rinsed & 0.031 & 0.038 \\
\hline
\end{tabular}

Table 4. Residue levels of the 3 antibiotics used for allograft decontamination in EHB

\begin{tabular}{|c|c|c|c|c|c|c|}
\hline \multirow[t]{3}{*}{ Allograft type } & \multicolumn{6}{|c|}{ Antibiotic } \\
\hline & \multicolumn{2}{|c|}{ Vancomycin $\mathrm{HCl}, \%$} & \multicolumn{2}{|c|}{ Lincomycin $\mathrm{HCl}, \%$} & \multicolumn{2}{|c|}{ Polymyxin $\mathrm{HCl}$, \% } \\
\hline & AV & PV & $\mathrm{AV}$ & PV & AV & PV \\
\hline Treated and rinsed & 0.002 & 0.003 & 0.002 & 0.004 & 0.00 & 0.00 \\
\hline Treated and not rinsed & 0.002 & 0.003 & 0.0009 & 0.003 & 0.00 & 0.00 \\
\hline
\end{tabular}



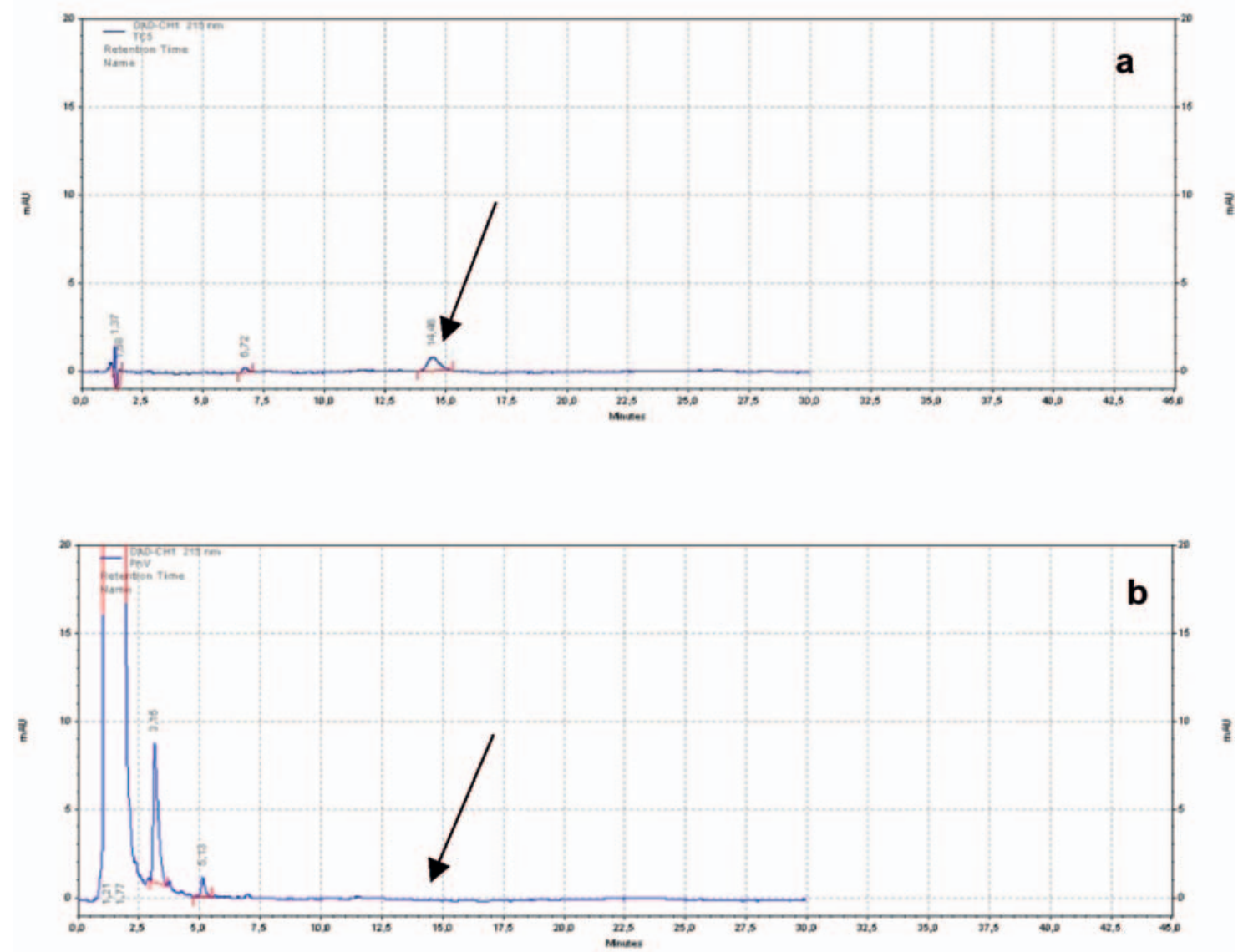

Fig. 1. Chromatograms of residual antibiotics. (A) Polymyxin sulfate,

(B) linomycin $\mathrm{HCl}$,

(C) vancomycin $\mathrm{HCl}$ (a, control; b, aortic valve; c, pulmonary valve).

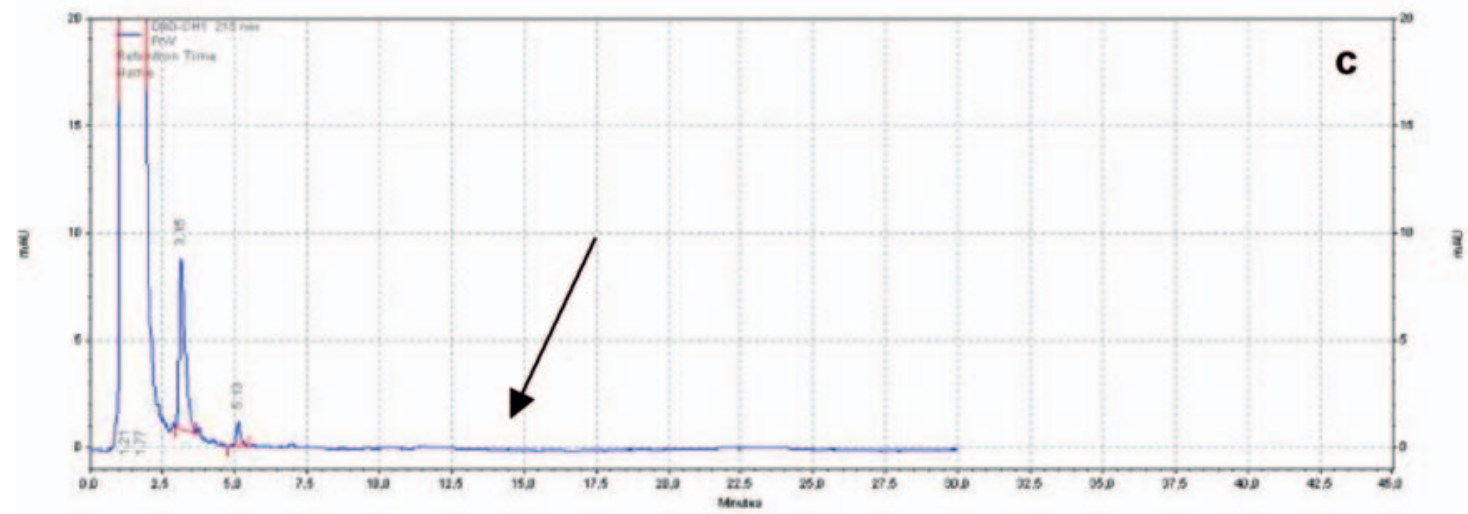

antibiotics in the initial testing. Further, we calculated the amount of each antibiotic starting from the calibration line. Vancomycin $\mathrm{HCl}$ was present at $18.14 \mu \mathrm{g} / \mathrm{g}$ in the non-rinsed and at $10.74 \mu \mathrm{g} / \mathrm{g}$ in the rinsed $\mathrm{AVs}$ and at $16.67 \mu \mathrm{g} / \mathrm{g}$ in the non-rinsed and $11.92 \mu \mathrm{g} / \mathrm{g}$ in the rinsed PVs. On the contrary, the concentration of lincomycin $\mathrm{HCl}$ in the non-rinsed allografts was 6.72 and $7.58 \mu \mathrm{g} / \mathrm{g}$ for the AVs and PVs, respectively, and in the rinsed allografts it was 8.44 and $8.68 \mu \mathrm{g} / \mathrm{g}$ in the AVs and PVs, respectively (table 3 ).
The chromatograms in figure 1 show the peak concentrations of the 3 antibiotics in the examined extraction solution and the time of their release for each of the 3 antibiotics of the EHB cocktail.

The thresholds of the residues of the 2 retained antibiotics in the allograft tissue were largely below the thresholds declared by the ICH Q3B (impurities in new drug products), which are $0.05 \%$ for vancomycin $\mathrm{HCl}$ and lincomycin $\mathrm{HCl}$ and below $0.01 \%$ for polymyxin B sulfate (table 4 ). 

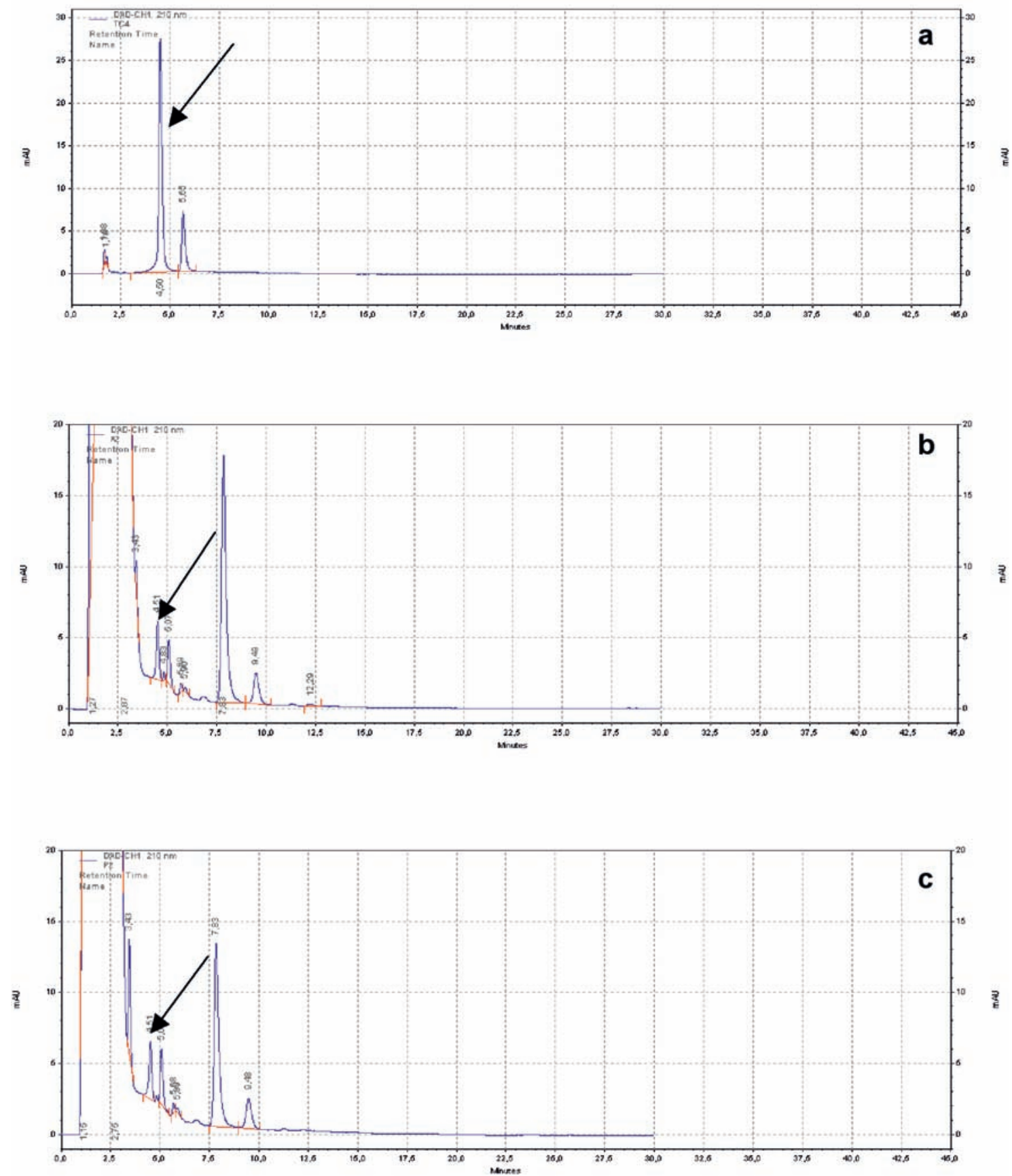

\section{Discussion}

The clinical use of heart valve and vascular allografts has been markedly limited by their availability [3]. Therefore, the retrieval of the allograft source material from the NHBDs was envisaged as one of the possibilities for increasing the yield of cardiovascular allografts. Consequently, some of the procured cardiovascular tissues arriving in the Tissue Establishments are primarily contaminated [8]. Earlier methods used for allograft decontamination were harmful for allograft integrity [14-19].
In 1969, Magdi Yacoub and Bryan Barratt-Boyes introduced the antibiotic decontamination of heart valve allografts [19, 20]. Different protocols (with varying combinations of antibiotics, duration of incubation, and temperature conditions) were adopted in different Tissue Establishments [3, 4, 5, 19, 20], with relatively good success in the eradication of contaminant germs. However, some antibiotics, being part of the decontamination cocktail, may have led to premature allograft deterioration, necessitating reoperation within a few years and thereby potentially endangering the patient's life. For this reason, many 

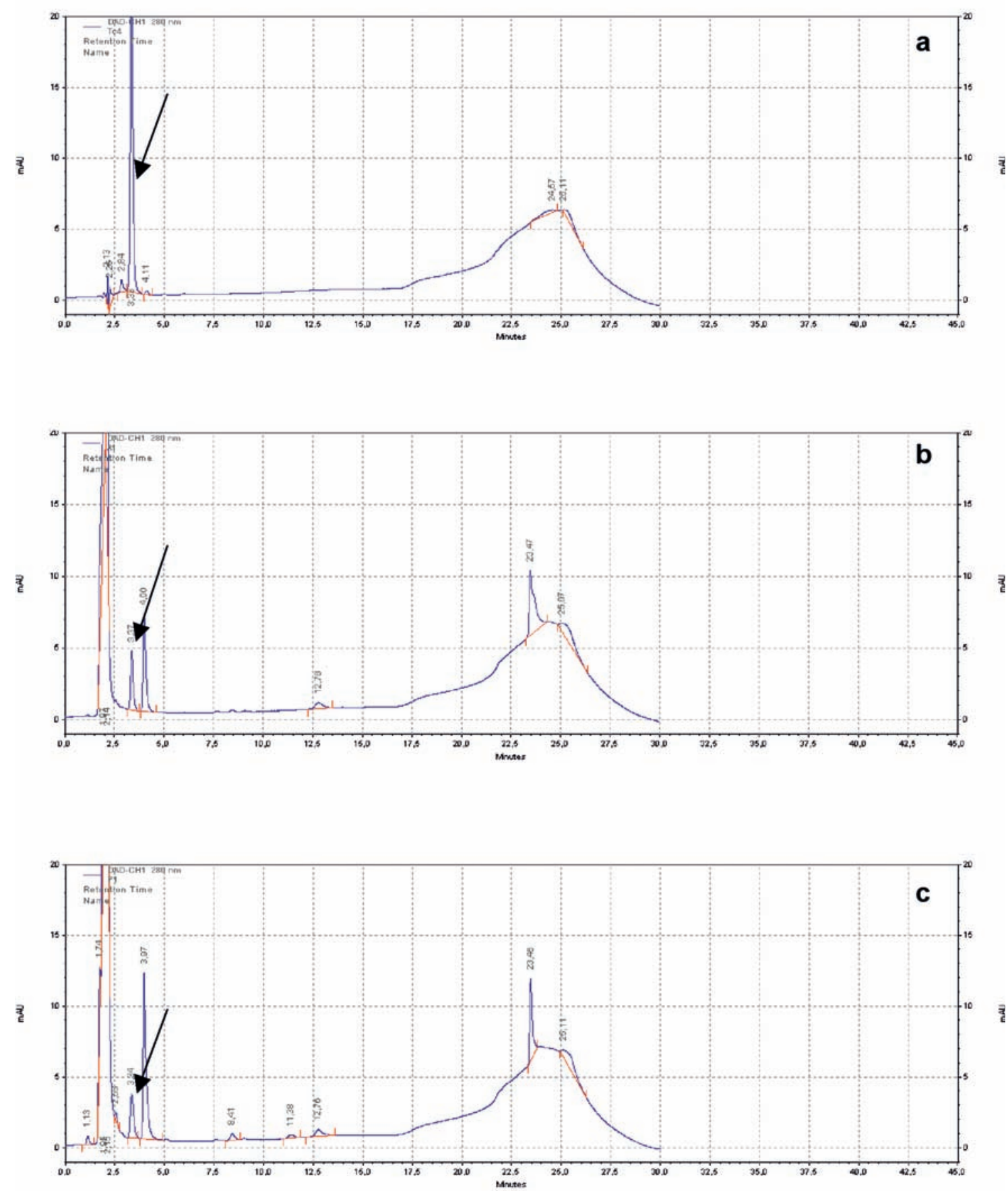

Tissue Establishments have adopted the less toxic antibiotics and accepted a decrease in the yield of allografts due to insufficient decontamination. Every year, as many as $5-10 \%$ of all processed allografts have been discarded for insufficient decontamination in our Tissue Establishment [2]. However, due to the low toxicity of our antibiotics cocktail, the quality of the heart valve and vascular allografts was high and the rate of explantation of these allografts was relatively low [11,21].

Following the European Directives 2004/23EC and 2006/86 EC, the European Association of Tissue Banking Standards and the Belgian Standards on Tissue Banking, traceability of all the substances coming into contact with the prepared human tissues for human therapeutic application is necessary. The authors of this study analyzed the traces of residual antibiotics in the heart valve allografts after the preparation of the allograft for implantation (thawing and dilution). As at the end of incubation in the antibiotic cocktail the antibiotics are supposed to be removed from the allograft tissue, our purpose was to search for residues of these antibiotics that might have been retained in the tissue. 2 of the 3 antibiotics of the 
EHB cocktail were retained in the heart valve allografts: vancomycin $\mathrm{HCl}$ and lincomycin $\mathrm{HCl}$.

According to the World Health Organization (WHO), the minimum inhibitory concentration (MIC) is the lowest concentration of 1 antibiotic to inhibit the visible growth of 1 germ. The MIC of the 3 antibiotics of the EHB cocktail against Staphylococcus aureus are $4-16 \mu \mathrm{g} / \mathrm{ml}$ for vancomycin $\mathrm{HCl}$ [22], 0.125-1 $\mu \mathrm{g} / \mathrm{ml}$ for 21 different germs for lincomycin $\mathrm{HCl}$ [23], and $0.01-14 \mu \mathrm{g} / \mathrm{ml}$ for polymyxin B sulfate [24].

The maximum daily doses of the antibiotics of our cocktail are the following: 2.0, 1.8 and $0.4 \mathrm{~g}$ for vancomycin $\mathrm{HCl}$, lincomycin $\mathrm{HCl}$ and polymyxine $\mathrm{B}$ sulfate, respectively. Following these levels and applying the ICH Q3B standard (impurities in new drug products), the thresholds of these 3 antibiotics are $0.05 \%$ for vancomycin $\mathrm{HCl}$ and lincomycin $\mathrm{HCl}$ and $0.01 \%$ for polymyxin B sulfate. In this study, the traces of vancomycin and lincomycin found in the heart valve allografts were $\leq 0.05 \%$ (vancomycin, 0.075 for $\mathrm{AVs}$ and 0.031 for PVs; lincomycin, 0.0135 for AVs and 0.035 for PVs), whereas polymyxin B was not retained in any allograft tissue sample after rinsing. These concentrations do not present any risk for the patient receiving the EHB cryopreserved heart valve and/or vascular allograft.

The antibiotic cocktail used in EHB contains 3 low-concentration antibiotics that are largely below their therapeutic dosage in clinical practice. Combination of these antibiotics is supposed to cover a huge bacterial spectrum (Gram-positive, Gram-negative germs, aerobic and anaerobic germs) with low toxicity for in vitro use. Each of the 3 antibiotics has shown potentially toxic effects during in vivo use (nephrotoxicity, neurotoxicity, and hepatotoxicity), when used for the eradication of important infections and septic states of the patients. However, their use in our antibiotics cocktail is restricted to only a temporary contact with the tissue (during the allograft processing), followed by their removal from the tissue before their final preparation for implantation into the patient. Indeed, their amounts in the allograft are very low, as shown in this study. Although residues of vancomycin $\mathrm{HCl}$ and lincomycin $\mathrm{HCl}$ are detected in all heart valve allografts, their concentrations were very low and without risk for the allograft recipient.

Polymyxin B was not detected in any of the allograft samples. In vitro, after $72 \mathrm{~h}$, this antibiotic is inactivated in the heart tissue because of its affinity to the phospholipids of the cell membranes [25]. This antibiotic is relatively toxic for some tissues. However, due to its ability to neutralize the endotoxin in Gram-negative infections, its use is important for the destruction of Gram-negative germs in the allograft [22]. However, polymyxin B shows important toxicity for liver and kidneys and is known as a releaser of histamines in the body, which may provoke hypersensitivity reactions. However, due to the fact that this antibiotic is not retained in the allograft tissue at all, it is safe to use this antibiotic in vitro for allograft decontamination. Furthermore, there are no reports of any toxic effect of heart valve allografts during the EHB's long experience with allograft allocation worldwide. On the contrary, a very low recurrence of infections was reported by diverse authors [7, 14, 18-20, 26].

Heart valve and vascular allografts have shown increased resistance to infection. Therefore, they are preferably used by cardiac and/or vascular surgeons for the treatment of endocarditis or infected vascular prostheses [3]. There have been controversial opinions as to why the allografts show such an increased resistance to infection: either due to the viable cellular components or due to the remaining antibiotics in the allograft tissue $[3,5,7,14,20,26]$. The reason for this increased resistance to infection might be due to residual concentrations of the antibiotics that are used for their decontamination. This is why many cardiac surgeons prefer allografts for the treatment of heart valve endocarditis rather than the prosthetic material.

\section{Conclusions}

Although residues of vancomycin $\mathrm{HCl}$ and lincomycin $\mathrm{HCl}$ were detected in the cryopreserved human heart valve allografts at the end of processing, their concentrations were largely below the daily therapeutic doses of these antibiotics and they do not present any risk for the allograft recipient. The presence of the antibiotics in the tissue may even be the reason for the increased resistance of the heart valve and vascular allografts against infection in the early period after implantation. This is particularly important when treating cases with infection problems (endocarditis, infection of prosthetic material).

\section{Acknowledgement}

The authors would like to thank Ms. C. Vantomme and Ms. S. Jashari for the technical assistance in preparing of this paper.

\section{Disclosure Statement}

The authors declared no conflict of interest.

\section{References}

1 Tabaku M, Jashari R, Carton HF, Du Verger A, Van Hoeck B, Vanderkelen A: Processing of cardiovascular allografts: effectiveness of European Homograft Bank (EHB) antimicrobial treatment (cool decontamination protocol with low concentration of antibiotics). Cell Tissue Bank 2004;5:261-266.
2 Fan YD, Van Hoeck B, Holovska V, Jashari R: Evaluation of decontamination process of heart valve and artery tissues in European Homograft Bank (EHB): a retrospective study of 1,055 cases. Cell Tissue Bank 2011;DOI: 10.1007/s10561-011-9255-3.
3 Gall K, Smith S, Willmette C, Wong M, O'Brien M: Allograft heart valve sterilization: a six-year in-depth analysis of a twenty-five-year experience with low-dose antibiotics. J Thorac Cardiovasc Surg 1995;110:680-687. 
4 Strickett MG, Barratt-Boyes BG, MacCoulloch D: Disinfection of human heart valve allografts with antibiotics in low concentration. Pathology 1983;15:457-462.

5 Wain WH, Pearce HM, Riddle RW, Ross DN: A re-evaluation of antibiotic sterilization of heart valve allografts. Thorax 1977;32:740-742.

6 Hunt CJ, Caffrey EA, Large SR: Factors affecting the yield of cardiac valve allografts from living unrelated donors. Eur J Cardiothorac Surg 1998;13:71-77.

7 O'Brien MF: Allograft aortic root replacement: standardization and simplification of technique. Ann Thorac Surg 1995;60(suppl 2):S92-S94.

8 Jashari R, Tabaku M, Van Hoeck B, Cochéz C, Callant M, Vanderkelen A: Decontamination of heart valve and arterial allografts in the European Homograft Bank (EHB): comparison of two different antibiotic cocktails in low temperature conditions. Cell Tissue Bank 2007;8:247-255.

9 Hu JF, Gilmer L, Hopkins R, Wolfinbarger L Jr: Effects of antibiotics on cellular viability in porcine heart valve tissue. Cardiovasc Res 1989;23:960-964.

10 Leeming JP, Lovering AM, Hunt CJ: Residual antibiotics in allograft heart valve tissue sample following antibiotic disinfection. J Hosp Infect 2005;60:231-234

-11 Jashari R, Van Hoeck B, Tabaku M, Vanderkelen A: Banking of the human heart valves and arteries at the European Homograft Bank (RHB) - overview of a 14-year activity in this International Association in Brussels. Cell Tissue Bank 2004;5:239-251.

12 Council of Europe: European Pharmacopea, ed 6, 6.6.

13 Council of Europe: Pharmeuropa 2008, vol 20, no 1.

14 Sugimoto JT, Krap RB: Homografts and cryopreserved valves. Cardiac Surg State Art Rev 1987;1:295-315.

15 Longmore DB, Lockey E, Ross DN, Pickering BN: The preparation of aorticvalve homografts. Lancet 1966;2:463-464.

16 Beach PM, Bowmann FO Jr, Kaiser GA, Malm JR: Frozen irradiated aortic valve homografts. Long-term evaluation. N Y State J Med 1973;73:651-654.

17 Smith JC: The pathology of human aortic valve homografts. Thorax 1967;22:114 138.

18 Manhas DR, Mohri H, Merendino KA: Late results of beta-propiolactone sterilized aortic homograft valves. A study of fifty-one patients followed up five to seven and a half years. Am J Surg 1973;126:255-262.

19 Yacoub M, Kittle CF: Sterilization of valve homografts by antibiotic solutions. Circulation 1970;41(suppl 5):II29-II32.

20 Barratt-Boyes BG, Roche AH, Brandt PW, Smith JC, Lowe JB: Aortic homograft valve replacement. A long-term follow-up of an initial series of $101 \mathrm{pa}$ tients. Circulation 1969;40:763-775.

-21 Jashari R, Goffin Y, Vanderkelen A, Van Hoeck B, du Verger A, Fan Y, Holovska V, Brahy O: European homograft bank: twenty years of cardiovascular tissue banking and collaboration with transplant coordination in Europe. Transplant Proc 2010;42:183-189.

22 Dykhuizen RS, Harvey G, Stephanson N, Natwani D, Gould IM: Protein binding and serum bacterial activities of vancomycin and teicoplanin. Antimicrob Agents Chemother 1995;39:1842-1847.

23 Pfizer Canada Inc.: Lincomycin, Product Monograph, September 2003, revised April 2008.

24 Duwe AK, Rupar CA, Horsman GB, Vas SI: In vitro cytotoxicity and antibiotic activity of polymyxin B nonapeptide. Antimicrob Agents Chemother 1986;30: 340-341.

25 Kunin CM, Bugg A: Binding of polymyxin antibiotics to tissue: the major determinant of distribution and persistence in the body. J Infect Dis 1971;124:394-400.

26 Yacoub MH, Knight E, Towers M, Somerwille W: Aortic valve replacement using fresh unstented homografts. Br Heart J 1973;35:555-556. 